Radilova, O., Ziomek, A. (2020). Fundraising competitive forces of small art and cultural NGOs during the crisis. W: M. Ćwiklicki, K. Sienkiewicz-Małyjurek, (red.). Ekonomia Społeczna. Przedsiębiorczość społeczna w czasie kryzysu (s. 92-106). Kraków: Uniwersytet Ekonomiczny w Krakowie. https://doi.org/10.15678/ES.2020.2.08

\title{
Fundraising competitive forces of small art and cultural NGOs during the crisis
}

\author{
Olesya Radilova, Agnieszka Ziomek
}

\begin{abstract}
The paper provides an analysis on fundraising competitive forces of small art and culture organizations in order to identify optimal features of fundraising strategy development during and after crisis time when absence of donors becomes a pressing issue. The analysis is fulfilled based on Michael Porter five forces model structure. Fundraising strategies should focus on intensive development of advanced communication with donors through modern technology application and reflect an integral vision of social needs which is the key success factor of fundraising strategy implementation in independent autonomous organizations.

Financial resources in nonprofit sector seriously affect the stability of programs implementation. The lack of stability undermines organization efficiency what is evident to donors. This requires formulation of strategy for professional and repetitive fundraising.
\end{abstract}

Key words: fundraising; small; medium; cultural; non-profit; organization

JEL Code: L31, L23

\section{Introduction}

The main subject of analysis of this paper is the small art and cultural non-profit organizations (NPOs). Their small scale comes from initial step of development. Such a organizations often work with people who are professional in work in social utility but do not have enough skills for strategy development and need to learn planning fundraising and its strategy implementation. Art and cultural sector organization are being recognised by donors as reflecting secondary importance regarding consumer needs. However they play an important role in society development and people empowerment (Alstrom et al., 2009).

The main purpose of paper is the identification of optimal features of fundraising strategy development. Those features reveal through social and economic status of society and are determined by competitive forces of the non-profit sector. Small art and cultural organizations are affected by competition of relatively bigger organizations which have been consistently funded for a long time by public grants. So to be effective in fundraising non-profits first need to acknowledge the competition performance in a sector and its competitive forces to overcome the barriers of donation access. Mentioned barriers occur not only during crisis time but are also visible beyond it.

According to Michael Porter (1996), competition between for-profit companies is not about who is the biggest, it is about who is the most profitable. Profitability and competitiveness 
background in this approach is defined by Porter's Five Forces model: customers power, suppliers power, threat of substitutes products or services, threat of new entrants, rivalry power.

Any economic entity deals with these five powers at least. According to M. Porter (2008), forces include the resources and processes which matter for business development. These relate to the number and density of customers and suppliers, the proximity of substitutes and their impact on the ability to raise the prices, and also threats to vertical integration, regulatory and financial barriers to market entry and exit. The model synthetically defines the possibilities and ways of strengthening the position within the current market concentration and its structure of entities. The focus is on the nature of competition typical for the industry and type of production (Gnjidic, 2018).

Porter's Five Forces model could be applicable for nonprofits with some adaptations and could be used for investigating the competition for donations from different funding sources and making a strategic choice within a wider context (Piana, 2005). Competitive forces help NGOs to evaluate the market attractiveness criteria and understand the level of competition within the non-profit art and culture market sector as well as weaknesses and strengths to enhance fundraising effectiveness.

Authors of Americans Speak Out About The Arts Report (2018), claims that when it comes to contributing to the arts, one in four has donated money during the 2018 year to an arts or cultural organization, such as a museum, community arts center, or a public broadcasting station. According to "Giving USA 2019 Report" (2019), only 5\% (\$19,49B) of total annual contribution $(\$ 427,71 B)$ was donated to art and culture in 2018 , where $68 \%$ of donations were made by individuals. Art donation is one of the least popular causes to support. To compare with the other philanthropy spheres the number of individual donors in small art and culture is very little making this field a fairly new component of individual giving even in UK and US. Significant funding disproportion exists in donating to big organizations granted by amounts of funds exceeding quota offered to small scale nonprofits. For small art and cultural organizations the importance of grants is very high due to a little number of individual donors who weigh interest of support between small and big art and cultural NGO's. In result there are few donors who support art and cultural NPOs. Significance of their power is high because of the availability of alternative ways to donate, switching costs, availability of information regarding other NGOs which gives the possibility to easily compare the conditions offered by different art and cultural nonprofits (Kafel, Ziębicki, 2009, Hamann et al, 2013).

The first section of this paper focuses on literature review and reports regarding individual private and institutional donating to small art and cultural nonprofits. This section is followed by an analysis of fundraising competitive forces within the structure of Porter five forces model. In the third section, based on mentioned analysis, paper provides insights on features shaping strategy for attracting donations through fundraising by small art and cultural nonprofits.

\section{Literature review}

According to Piana, competition is a process of different entities to compete for an optimal share of limited resources. The market where art and cultural nonprofits operate is very competitive in terms of funding sources that are necessary to advance the organizational mission (Piana, 2001; 2005). So the competitiveness is equally important to non-profit organizations as independence and its autonomy. Now as never before the art and cultural NGO sector shows an extreme competitive growth in terms of seeking funding due to in 2020 COVID-19 crisis had 
a catastrophic impact on art and cultural sector. As a result of crisis not only incomes from their own commercial activities has fallen but also from corporate donors who themselves were impacted by this crisis as well (Deitrick, et al, 2020).

The research which investigated competition among nonprofit organizations and its impact on fundraising was made by Rose-Ackerman (1982) and Harrison, Thornton (2015). In this model, due to competition, the fundraising costs are increasing and nonprofits maximize their revenues by choosing different fundraising tactics and extend expenditures budget on fundraising. With a large number of small non-profit organizations in a competitive charity with a free entry market, most of their revenue will be spent on gaining fundraising, and fundraising strategy can become excessive. From another side, Bose (2015) in his paper shows that competition among nonprofits could increase the aggregate donations by all donors in the market. But in spite of this increase in the margin amount of total donations, the average donations received per nonprofit decrease. It is harmful because it encourages competition between organizations for a specific donor, increases advertising and fundraising budgets, and leads to excessive fundraising that nonprofits undertake to deal by competing (Bose, 2015). Competition often affects the financial stability of an organization, and influences the quality of the provided service to its beneficiaries so that it may reduce social welfare. Tuckman and Chang (1991) claim that to leverage competition potential outcomes is cushioned by financial flexibility of budget which in turn accounts for a financial stability. They formulated a set of four determinants of financial flexibility of USA nonprofits as operation activity encompassing equity balances, diversified revenue sources, high administrative costs, as a reserve of funds used during a crisis and high operating margins. Authors showed high usefulness of these adopted conditions also for assessing organization survivability. Hager (2001) performed a research on determinants of financial stability focused on art organizations and claims that applicability of the measures varied substantially. For NGO theatres all measures were relevant but for culture centres and others different combinations of measures proved useful along with recent work of Greenlee and Trussel (2000). Mikołajczak (2019) claims that diversification is crucial for gaining financial stability of revenue because it leads to independence of public sources and makes nonprofits to intensify its activity towards individual and institutional donators. Sustainable and flexible financing bring stability but for many NGO desire to meet the financial needs of an organization often leads to commercialisation of projects and broadening of the scope of financial resources for taxed activities. Therefore, the search for financial stability leads to differentiation of financial sources, including fundraising.

In the case of art and culture organizations, it has also been proven that the increase in revenue from governmental sources leads to a decrease from private giving (Seongho et al., 2017; Diaz Diaz et al. 2017). This is due to several reasons, namely donors treat tax financed donations as a substitute for their voluntary donations, therefore subsidies have a negative effect on a non-profit organization's fundraising effort especially when fundraising activities is considered to be costly for these organizations (Ziębicki, (2008). Finally, government grants reduce an organization's incentive to work hard and lower organizational efficiency of fundraising efforts towards making giving decisions. So both low private giving and efficiency in decision making process will affect competitive position of art organizations when government grant dominate the revenue stream.

When deciding on fundraising than organization budget is usually affected by fluctuating donations. This is challenging for non-profit strategy planning because programmes budget may be substituted for overhead costs and fundraising budget. Beneficiaries needs oriented 
programs are testimony for donors who do not favour high overhead costs ratio since too much money is directed to administration and fundraising (Burkart at al., 2018). As a result it may impact administrative capacities negatively and bring an inverse impact on organization competitiveness.

In relation to the studies above paper provides some features shaping fundraising strategy development. As non-profits vary in terms of size, numbers of employees, structure, the sphere of work and available resources, there is no only one right way to develop a fundraising strategy. The main idea of fundraising strategy is to describe: an overall direction - a common plan for one-, three or five-years period, fundraising objectives, key strategies for different segments of donors, such us individual, corporate or public, tactical plan for each segment, calculate the cost of raising funds, to set a schedule with the main milestones, and describe the main indicators to control and monitor the results (Jay et al., 2014). Bodine (2020) claims that the key step of fundraising strategy development is market segmentation which helps to identify suitable types of donors and customize specific offers to smaller target audience to appeal their need and interests, personalize communications and build healthy relationships with donors. The overall strategy outlines the long-term goals the organization intends to do but tactical plan outlines short-term action plan, schedule and Key Performance Indicators to measures a success of the exist strategies. Tactical plan contains all detailed fundraising actions for every donor segment that will be undertaken (Metha, 2016). Since, the organizations knows far more about today than about the future, tactical planning is more detailed and today-connected (Nielsen, 2019). Tactical plan should include a budget of each tactics and scheduling. While planning the budgets it is necessary to take into account appropriate fundraising costs that could be found in various benchmarking reports. While planning the dates of each activity it is necessary to distribute the load evenly to prevent staff burnout (Jay et al., 2014). While implementing a tactical plan not all of organizational fundraising ideas will work out and, or it may appear new sources along the way. Moreover small non-profits entering new markets and engaging new donors with new activities take a high level of risk (Heng, 2019; Vasicek et al., 2019). So, they could plan in a shorter period, test if their small steps help them to meet the goal, be ready for changes along the way. The situation of uncertainties is very similar to for-profits start-ups that is why it could be useful to take into account HADI-cycle (Hypothesis, Action, Data, Insight) technic which came from start-up world (Mingaleva, 2019).

In the light of foregoing fundraising strategy issue brings a question what are the competitive strengths of fundraising for small art and culture nonprofits? The Porter's Five Forces model will support continuation of analysis.

\section{Porter's Five Forces framework relevance for non-profit sector}

Investigating non-profit organization area of activity focused on fundraising in competitive environment based on Porter's Five Forces model analysis focus in line of model definition on supplier and customer power, threat of substitutes, threat of new entrance, who regulate competition and natural rivalry power in a sector (Drzewiecki, 2012). Consequently by secondary data the breakdown of factors below presented is analyzed in terms of each market element.

The power of suppliers

In small art and cultural nonprofits suppliers are identified as donors who provide donations and one of the revenue source. The power of suppliers can be low if there are many 
donors with small donation each, they act independently and the service which organization provides is unique and very different from any other nonprofits. The bargaining power of suppliers is an important factor due to the structure of financial support acquired by NGO's. When the main source of income of art NGOs become public funding, institutions who provide this funding have a great impact on the development of organizations. Based on Arts Council England Report (2018) annual income of Arts Council of arts and cultural organizations in England from 2009 to 2018 consisted of earned revenue equal to about 33\% and the remaining $67 \%$ was generated from sponsorships business organizations, corporate membership schemes, foundations and money received from the general public for which no benefit is offered in return. So, bigger part of income were donations from individual donors whose power as suppliers comes from influencing organizational strategy development. Large funders influence small nonprofits even more because due to the lack of resources nonprofits often change their goals and projects to meet the grants criteria. During the current COVID crisis in 2020 even the fact that public individual funding has reduced slightly it still remains the main funding source for many small art and cultural organizations, and has a big power to influence competition between nonprofits on offered grants (Bolton et al., 2017). Some foundations who support art and cultural nonprofits postponed opening their calls, and it became challenging to apply for open calls because organizations cannot plan continuation their activities due to the lack of certainty (Polivtseva, 2020). NGO can be on the verge of closing many programs due to dependence on suspended funding. From the one hand, it could impact a lot NGO's future development, but from the other hand it became clear that art and cultural NGOs need to change their approach to financial sustainability and to consider development of recurrent individual donations and memberships by fundraising.

Supplier power is being reflected also by phenomenon of the crowd-out effect of public funding, as a potential impact of public grants on individual donating. Government grants make a crowding-out effect because potential donors, who are at the same time taxpayers, view their taxes as substitutes for private donations (Andreoni et al., 2003; Sherlock, 2009). An increase in public grants cause charities to decrease, which subsequently reduces the overall effectiveness of the public grant. Studies of Sherlock (2019) suggest that art nonprofits in USA found that a $\$ 1,000$ increase in government grants decreases arts organizations' fundraising by $\$ 264,70$. The results of the research testify a negative relationship between government funding and fundraising efforts for the arts organizations and that crowd-out in fundraising efforts in art organizations is greater than in organizations who provide social service. All donors balance between norms, values, and cost-benefit rule. Many people do not recognize art and cultural organizations as those who provide real help to society and those who need financial support from individuals. Mostly art and cultural organizations are considered as those which should be supported by the government and to change this attitude organizations have to show the real situation and communicate their needs. Art and cultural NGOs in the UK receive less than $10 \%$ of total income from individual donors (Arts Council England, 2018), and the competition aimed to recruit individual donors also by fundraising is increasing dramatically due to understanding that this type of funding source is much more sustainable than public grants.

Organizations in the most compete for general public recognition and for beneficiaries and donors retention. According to Vogel (2017) in 2016 45\% donations were obtained due to the average donor retention at the NGO. The conclusion is that the other $55 \%$ switched to other NGOs or decided to spend their donations for some substitute products. Loyal donors 
are those who support organization from time to time. Increase in donors retention even in a small amount could positively impact NGO's profitability. Many NGOs report that about 50\% of cash donors never donate again and switch to another organization (Jay at al., 2014). After the first donation the donor is waiting for individual feedback to decide to go further. The second time donation is always an indicator of starting donor-non-profit relationships. In case the loyalty it is a middle level of donorship periodical support of the organization still without a feel of the strong connection with the organization. In this case organization is affected by a switching costs which are in this case almost equal to zero. At the "top" level of loyalty a strong relationships make donors to support the organization even though other nonprofits are more competitive in the same field. This donors are more likely make a major or even legacy gift and switching cost for them are extremely high due to they consider themselves as a part of the project (Jay et al., 2014). The recurrent donors make annually $42 \%$ more than one-time donors (Te, 2020). So, the necessity of clear and personal communication becomes one of the main factors to decrease the power of switching costs and rise its level. Moreover now due to people who become more informed about non-profit organizations their expectations regarding accountability and transparency increase. In a situation of the full transparency, when any of the donors can request financial information at any time, non-profit organizations have to put much more effort into writing reports, financial planning, and accountability to remain attractive to donors by frequent communication (Behn, 2010). Rose-Ackerman (1982) shows that donors which have preferred ideology orientation tend to donate to nonprofits that match their goals. So, the main role in retention plays the loyalty of people who support the organization and NGO's close relationships with donors.

One of the main factors to gain donors retention is a trust norm. Due to the fact that there are NGOs that do not report on the intended use of funds on Internet raise the quantity of fraud charity cases, this creates a wave of distrust that affects the entire sector. From the public point of view if there are organizations that spend money irresponsibly, society's perception of the non-commercial sector in terms of financial spending is often negative (O'Really, 2018). According to Chronicle survey conducted in USA in 2015, 35\% of Americans said they had little or no confidence in charities. Experts blame that it happens due to charities' failure to promote trust. In Chronicle of Philantropy about $80 \%$ of survey participants said that charities do a very good job in helping people, but the main issue is revenue: $30 \%$ are unsatisfied with the way of charities spending money wisely; $41 \%$ stated that salaries for NGO's leaders are excessive; and 50 present said that while making a decision about donations, it is very important that charities spend a low amount on salaries, administration, fundraising, rent, utilities, information technology, financial management (Chronicle of Philanthropy, 2015).

Due to donor's trust many organizations are caught in a vicious circle that fuels constant underfunding of overhead costs and have disastrous effects. Donors have unrealistic expectations about nonprofit running costs. Nonprofits respond to this pressure in two ways:

- Non-profit leaders try to conform to donor's expectations by spending as little as possible on overhead and by reporting lower-than-actual overhead rates. The incorrect data could lead to decrease trust in the whole sphere.

- By skimping on overheads do not invest in the ability to fulfill their mission. They decrease costs on personnel education, do not invest in quality technics, do not buy good enough CRM systems, but this limited overhead investment is felt far beyond the office: old computers decrease the efficiency of work, poorly trained staff cannot help the organization to step to the next stage of the organization's development (Goggins et al., 2009). 
This underspending and underreporting leads to cycles that endlessly repeat to do more and more at less and less cost, and this drains nonprofits and make the competition for new donations even harder. To break this circle it is necessary to start a fearless conversation about these issues to refresh and make more realistic view regarding overheads (Goggins et al., 2009).

\section{The customer power}

On the one hand nonprofits deal with beneficiaries called customers represented by donators and on the other hand with beneficiaries in need to whom all programs are oriented. In the first case donors who provide help to NGO become both suppliers and customers. Donors who provide funds for NGOs from the one hand are suppliers because NGO could follow its mission with help of these resources, but from the other hand by providing these resources donors become customers because by donating they "buy" a sense of belonging to mission, and gain the opportunity to influence on social development by becoming a party of the solution that NGO implements through its programs (O'Reilly, 2018). On the other hand NGO stay oriented on beneficiaries in a light of non-profit organization's mission which does not revolve around profits, but about causes they aimed to solve.

While analyzing a customer power in NGO fundraising activity sphere we find that beneficiaries compare the quality, performance and easily switch to substitutes which have low switching cost (Alstrom et al., 2009). This power will be strong when beneficiaries could easily switch between different NGOs and choose other alternatives on how to spend money they donate NGO in case of donators. The same power goes down when beneficiaries live in remote and neglected areas with the scarcity of nonprofit infrastructure. Community living in poor environment not equipped by NGO creativity and power deals only with public and on-profit services delivered. The choice within this capabilities conditioned by not the only financial factor can be targeted nonprofits (Woronkowicz et al., 2017).

\section{The threat of substitutes}

Substitutes are a part of NGO fundraising strategy of attracting donors in the non-profit activity area. Substitutes refer to program content and its significance to environment. The threat comes also with the fact that a local government unit or a private entity can take the role of an NGO, and whether beneficiaries stay with NGO depends on whether they provide better choices for beneficiaries, who are then better able to satisfy their needs. So when planning fundraising organizations faces not only with individual customers but also with collective group what matters for donations gaining. When society or part of it shares a common vision of the problem and its solution, then for NGO offering authorship solution it will be easier to attract donors sharing this vision. The lack of social consensus on NGO supportive programs will lead to stronger competition among organizations while organizations will need to constantly defend their point of view on how to solve the problem and will compete for resources but parallelly to that fundraising expenses will increase (Heng, 2019). In the case of art organizations, it will be necessary to prove that art and cultural initiatives can solve the social problems of people at-risk by providing them equal access to art and culture. The same time in society prevailing added value is to solve the problems of people from social risk groups like employment and humanitarian assistance, psychological support or helping with education. Many art and cultural organization engage art and culture divided constituencies and donors in economically depressed or rural areas where nonprofit infrastructure is rarely developed. In this case, the solution to the social problem under equal consideration involves several alternatives, and 
competition of art NGOs for resources can be particularly intense. If society is aware of the problem and understands that the solution offered by an NGO is necessary, a homogeneous public opinion will tend to reduce competitive pressure and encourage joint solutions. While a fragmented public opinion will lead to a hardening of views and increased competition for financial resources (Ritchie et al., 2000). Moreover in attracting funding from individual donors to avoid threat of substitute programs that may be donated and could be selected nonprofits can't neglect integral vision of social needs which is behind the success of fundraising implementation (Bose, 2015).

\section{Threat of new entrants}

Threat of new entrants refers to overcoming potential barriers to enter the non-profit sector. Potentially barriers or obstacles are extremely low since still the amount of unsolved social problems in society needs many more initiatives than already exist. In art and cultural NGOs the main real barriers to enter the market are: a low number of social entrepreneurs, fundraising professionals and existence of fundraising skill gaps.

According to startup community AngelList, startups in art sphere occupy the last place among startups opened per year (AngelList, 2020). Artists who want to establish their art NGOs have to have a mix of all these different skills and qualities. Moreover any organizations looking for fundraisers meet the fact that fundraising activity need long term investments by these it become one of the barrier to enter the market for new entities (Drzewiecki, 2012). Other words leadership and personal development could help organizations to become more sustainable and competitive to compare with new entrants. The barriers also are a local legislation that prevents foreigners from opening non-profit organizations in the country, the monopolization of certain specific areas of activity by some NGOs on the market, and the loyalty of donors to existing charitable organizations (Rose-Ackerman, 1982).

The threat of new entrants discloses increased competition for donors which complicate the process of raising money for both new and previously existing NGOs. For new NGOs, the easier to enter the market the harder it is to oulast and predict stability of their income and fundraising costs.

The entrance to NGO's market is formed through channels by which resources are collected. Individual giving could be divided into three main channels in accordance to its mode everyday giving, peer-to-peer giving and giving day donations (Frost et al., 2017):

- Everyday giving includes donations made via on a nonprofit's website within a general year-round donation program or monthly giving programs, it could be a one-off donation for different year-round campaigns and events at different platforms as Youtube, Facebook, Instagram;

- Peer-to-peer donations includes donations driven toward peer-to-peer campaigns or events when individuals themselves create a personal fundraising page and solicit donations on behalf of an organization. This campaigns could be made in honor to run, walk or ride event, or a do-it-yourself personal fundraising campaign such as a "donate your birthday" campaign;

- Giving day donations includes all donations made typically in a period of 24-48 hours when organizations call donors to action through their short, time-based incentive. The most popular giving day donation initiatives are \#GivingTuesday worldwide, Red Nose Day campaign in UK (Nonprofits Source, 2020), and in Poland Wielka Orkiestra Świątecznej Pomocy. In case donors have different choices on how to support the organization in different ways - to become a member, to make their own fundraising in a favor of the organization, to make 
one-off donation via website, to subscribe on recurrent donation using VISA, PayPall, Yandex, Money, or other online services will give the organization the possibility to attract donors with different preferences and behavior (Bose, 2015). The Internet and new technologies give the opportunities to raise funds and to stay connected with donors who supported the organization with a one-off donation. Increasing the number of ways on how the donor is able to donate can increase the number of donations when everyone could choose the most comfortable method. The most suitable channels of donations become digital which provide a wide range of possibilities to make online donations from a laptop or mobile phone. However the charity sector stayed some steps behind the curve in using new technologies to communicate with their donors.

Small art and cultural organizations need to be very creative and offer alternative, unusual ways on how to support to be competitive and to attract the attention of potential donors. Especially during COVID-19 pandemic we witness the fact that social networks are filled with calls to support. Digital fundraising started developing very fast due to it becomes the only alternative to raise funds and to survive. But as small nonprofits in the most cases do not have resources to develop digital fundraising it becomes even more complicated to compete with big organizations.

\section{The rivalry power}

The way to gain individual power to rivalry NGO's by gaining donors and beneficiaries tent to differentiate activity by specialization. For example, they could solve different social problems by means of different art and cultural activities (circus, theater, contemporary dance). NGO could be far different in their ideology and a concept. Nonprofits could deal with their rivals through adjustments in fundraising expenses or through the effectiveness of their impact on public goods. NGO will be more attractive for donors when achieve greater impact with the same resources. This way the effectiveness of donations will be higher (Ritchie et al., 2000). Wealthy donors are mostly supporting big long time existed organizations in the "traditional" spheres like museums, operas or ballet. Bose (2015) found that $60 \%$ of all investment is flowing to the 50 largest recipients and to compete with them for donations on a local level is extremely difficult. In this case, small nonprofits may attenuate this force by implementing more impactful campaigns to determine local communities, create good user interface at the website or implement innovative technologies to gain resources.

Individual rivalry power results from competitive factors as better communication with donors, attractive design and image in social networks that the donors would like to associate themselves with, wide range of channels to donate and transparency of internal and external relations (Ziębicki, 2008; Gnjidic, 2018). A key concern for current and potential donors is how charities spend their money. If for individual donors the organization is clear about how nonprofits spend donations it become the top factor that might motivate them to donate to a particular charity and power the rivalry (Saxton et al., 2020).

Nevertheless rivals who work in the same field could make a greater impact and receive more funds together decreasing rivalry power of activity field. For nonprofit leaders it is advantageous to come together since they may reach perceived potential synergies in fundraising. It becomes easier to recruit donors and to increase their loyalty by cooperating non-profit organizations. It is because they raise funds from donations on higher-impact efforts (Piana, Real Collaboration A Guide for Grantmakers, 2001). This influence rivalry for donors by changing the market competition structure. Moreover, nonprofits are more focused on cooperation 
than for-profit organizations. Cooperation with existing rivals could help small art nonprofits to develop a unique selling proposition and to get competitive advantages over other donation-seeking organizations.

\section{Desired features of fundraising strategy development}

Based on the previous analysis of Porter's Five Forces framework we could identify features that art and cultural organizations should consider when developing their fundraising strategy for attracting individual donors in the crisis and after it completes. One of them is donor engagement through close collaboration and personalized communications. The more nonprofits understand donors and their behavior and what is their cause-driven passion the more effectively organizations could communicate and engage donors (Jay et al., 2014). One of the ways of engaging their donors is open free access to performances, concerts, workshops. It helps attracting attention and promoting their organization because people want to be advocates for cultural development (Te, 2020). Online reviews are also critical to their success, digital feedback is important for beneficiaries and donors. Donors want to see a year-round activity as a program results, how they have contributed, and the overall effectiveness of the organization (Burke, 2020). Most likely, the trend of digitalization and digital communications will only increase in the coming years, so charities, must effectively use their digital communications to reach their audience. Some charities are already well set up to do this, but based on research done by Media Trust and CharityComms, 53\% charities are facing challenges with producing digital content for example, films, vlogs, infographics; $41 \%$ of charities are facing challenges moving their services online; $40 \%$ are facing challenges with digital fundraising and communicating and engaging their stakeholders (CharityComms, 2020).

Technologies allow organizations to deliver great donor experience by using different services. For example platforms like Patreon or Steady give the possibility to become a member or patron of the organization in an easy way. Development of these services was determined by the important global trend of subscription economy growth. Over the past few years, have been observing a growth in the preference of both businesses and consumers to subscribe to services rather than buy products. Especially it is connected with software-as-a-service companies, media, education and content producers like Netflix, Lingualeo, Apple Music, Spotify and others. Organizations have to better manage a direct, complex, responsive, multi-channel relationship with its customers. Long term relationships building with customers become an absolutely key formula for growth. Subscription model implies a service that is paid for on a regular basis. The danger for subscription is that another, better offer might come along. Membership campaign is a subscription model with added value proposition. After becoming a member Members receive tangible rewards like special news-letter or online hangouts for patrons as a part of their subscription. It takes not only a possibility to support, but also have good customer experience, to be involved in organizational planning and development, have the ability to interact with other patrons and team members. Incorporating these new ways of engagement with proven fundraising and marketing will give the organization a chance to succeed even during the crisis. Membership is based on the intrinsic value of the work and high level of loyalty. People support nonprofits because they like what they do. They feel an affinity with the work which non-profit creates and have longer lifetime value due to they get not only privileges from nonprofits, they engaged in organizational development, realize the value that the organization brings and have a close communication with organizational team. 
So, the subscription-based membership programs could be a powerful factor affecting financial sustainability of the emerging project because monthly revenue allows to cover the minimum organizational costs and future salaries of key employees.

Expert Panel (2020) states that nonprofits spend $95 \%$ of their time raising funds, but only $5 \%$ on thanking donors. If to change that and to send timely, personal and specific gift "thank you" it will impact donor's retention. To show donors how their money will be used to achieve organizational mission is necessary to show how their money are appreciated. Donors should know that their gift has a value and brings a certain impact, regardless of the size of the gift. Organizations should develop and implement a strategy for continuous engagement and cultivation of donors, in which donors receive updated organizational information, rather than requests to donate. This may not guarantee a repeat donation, but it will provide common ground throughout the year. This could be a quarterly newsletter that informs recipients about the success, activities of the mission movement, and organizational and industry news (Expert Panel, Forbes Nonprofit Council, 2020).

The most donors are interested in non-profit organizations because they want to make a difference. Therefore, an important aspect of engaging donors is to build a dialogue firstly about the social issues that the nonprofit organization is focused of. This helps to build relationships around a common goal and set of values, an emotional connection, and a purpose to work with nonprofit organization (Horsley, 2019; Joslyn, 2019).

Change management and leadership development requires regular, succinct, honest, open and face-to-face dialog with people who involved into organizational development. In a time of rapidly changing world, all changes must relate to the overall goals and objectives of the organization. Missions need to be regularly refreshed and realigned with strategic goals in order to keep them relevant and appealing. It will help to resonate with potential donors and sponsors and motivate them to give. Another recognized tactic is to purposefully search for people who support the organization, often members or patrons, who can give an external objective perspective about changes. For many art and cultural organizations, it is good to have a variety of knowledgeable and skeptical stakeholders among their donors, audience, or Board of members. Transparency for trust seems to be crucial component of each nonprofit strategy. From $50 \%$ to $60 \%$ of people who were born after 1980 say that their decision to donate hinges greatly on whether they can see their gift's impact (Chung, 2016). The website of the organization should have all details exactly where donations go. To become more interactive it is necessary to translate donations amounts into tangible results, provide proof through visual content (Nelly et al., 2018).

\section{Conclusions}

In times of crisis many organizations suffer and fail because of scarcity of activity conditioned by limited donations. This paper has employed the five forces model to identify competitive advantage factors taken into consideration when planning fundraising strategies during crisis. It also highlights that leadership in small art and cultural organizations need to be supported by management skills to change the strategic point of view on external communication and gain ability to effective resource management.

The number of donors who support art and culture is extremely low compared to other big non-profit cultural organizations especially in crisis time. So, for small art and cultural nonprofits, donor engagement becomes one of the main challenges. The better nonprofits engage in 
mutual activity the better results they gain in reliance and trust of environment. This brings cause -driven passion donors to NPOs who offer recurrent support and emerge interest of the other donors.. It is extremely difficult to retain the donor who made a one-time donation in response to an urgency case appeal. Giving, in this case, is made because of the urgency motivation, and not because the donor identifies with the nonprofit cause (Jay et al., 2014). Incorporating the identified new ways of engagement in areas of fundraising and marketing will give the organization a chance to succeed even during the crisis. People recurrently support the nonprofits which do what donors identify with. Donors feel an affinity with the work which the non-profit creates as they get not only privileges from nonprofits, they engaged in organizational development, realize the value that the organization brings and have a close communication with organizational team. NGOs in subject activity field subject sector can build their market position in fundraising by individual acting and specialization or by partnership. To avoid rivalry, small nonprofit tend to engage in cooperation by which they may achieve the same positive impact with fewer resources. Integral vision of social needs by NGO and local society guarantee individual donating as people understand organization plan and share its value and its approach to problem solution. Being comprehensive and transparent in funds distribution can significantly contribute to gaining donors through channels offered by Internet platforms. The measures addressed to channel communication will make nonprofit activity attractive and encouraging like products or services ads on for profit market. This activity leads to increase a switching cost factor which leads consumer to NPOs friendly decision alternative. Organizations being in early phase of development or these that stay small by choice both operate in competitive markets and always need resources to implement projects. Therefore in and after the crisis franchising strategy is one of the ways they can improve nonprofit performance.

\section{Literature}

AhIstrom, D., Bruton, G. (2009). International Management: Strategy and Culture in the Emerging World. Mason: Cengage Learning.

Americans for the Arts. (2018). Americans Speak Out About The Arts in 2018 An In-Depth Look at Perceptions and Attitudes About the Arts in America. Americans for the Arts.

Andreoni, J., Payne, A. A. (2003). Do Government Grants to Private Charities Crowd out Giving or Fund-Raising? The American Economic Review, 93, 3, 792-812.

AngelList. (2020). Markets. Pobrano April 20, 2020 z lokalizacji https://angel.co/markets.

Arts Council England. (2018). National Portfolio Organisations and Major Partner Museums. Arts Council England.

Behn B.K., Devries, D., Lin, J. (2010). The determinants of transparency in nonprofit organizations: An exploratory study. Advances in International Accounting 7(26), 6-12 DOl: 10.1016/j.adiac.2009.12.001

Bodine, H. (2020). Donor Segmentation: What It Is, And Why It Matters. Pobrano March 25.03.2020, 2020 z lokalizacji https://www.causevox.com/blog/donor-segmentation-matters.

Bolton, M., Cooper, C. (2017). Capital Matters How to build financial resilience in the UK's arts and cultural sector, Pobrano March 25.03.2020, 2020 z lokalizacji https://static.a-n.co.uk/wp-content/uploads/2017/08/CapitalMatters-How-to-build-financial-resilience-in-the-UK\%E2\%80\%99s-arts-and-cultural-sector.pdf.

Bose, B. (2015). Effects of Nonprofit Competition on Charitable Donations. Seattle: University of Washington.

Burkart Ch., Wakolbinger T., Toyasaki F. (2018), Funks allocation in NPOs: The role of administrative cost ratios. Central European Journal of Operations Research, June 26(2), 307-309.

Burke, E. (2020). Drive Donations Year-Round With Nonprofit Impact Transparency. Pobrano April 25, 2020 z lokalizacji https://www.classy.org/blog/drive-donations-year-round-impact-transparency.

CAF Russia. (2014). Russia Giving. Research on individual giving in Russia. Moscow: CAF Russia.

Charities Aid Foundation. (2019). CAF UK Giving 2019. Kent: Charities Aid Foundation. 
CharityComms. (2020). Impact of COVID-19 on Charity Communications. CharityComms.

Chronicle of Philanthropy. (2015). How Nonprofits Can Gain the Public's Trust. Pobrano April 21, 2020 z lokalizacji https://www.philanthropy.com/specialreport/how-nonprofits-can-gain-the-pu/69.

Chung, E. (2016). How to Engage Different Generations of Donors. Pobrano April 23, 2020 z lokalizacji https://www. classy.org/blog/how-to-engage-different-generations-of-donors.

Deitrick, L., Tinkler, T., Strawser, C., Young, E. (2020). Nonprofit response to COVID-19: The immediate impacts of the COVID-19 pandemic on San Diego County nonprofits. San Diego, CA: The Nonprofit Institute, University of San Diego.

Drzewiecki J. (2012). Model biznesu z perspektywy przedsiębiorczości i przedsiębiorcy. W: H. Kościelniak (red.), Przedsiębiorczość. Szanse i wyzwania (s. 7-14), Politechnika Częstochowska, Częstochowa.

EMpower - The Emerging Markets Foundation. (2018). The Art of Fundraising A Practical Workbook of Tools and Strategies. Pobrano March 02.03, 2020 z lokalizacji https://empowerweb.org/: https://empowerweb.org/ assets/uploads/tools-resources/464/empower_fundraising_workbook_2018_2.pdf.

Esser, S. (2020). How to go community-funded in times of crisis. Pobrano April 23, 2020 https://app.livestorm.co/ steady-2/how-to-go-community-funded-in-times-of-crisis

Expert Panel, Forbes Nonprofit Council. (2020). Seven Effective Strategies For Improving Donor Retention Rates. Pobrano April 25, 2020 z lokalizacji https://www.forbes.com/sites/forbesnonprofitcouncil/2020/04/20/ seven-effective-strategies-for-improving-donor-retention-rates/\#67e07ad4d6fd.

Frost, K., Shanklin, T., Finney, J. Genuardi, I. (2017). Donation Trends by Channel: 2016 Donor Data Report. Kimbia. Pobrano March 02.03, 2020 z lokalizacji https://www.nonprofitpro.com/resource/donation-trends-bychannel-2016-donor-data-report.

Giving USA Report (2019). Giving USA Foundation, Pobrano June 25.03.2020, 2020 https://givingusa.org/givingusa-2019-americans-gave-427-71-billion-to-charity-in-2018-a mid-complex-year-for-charitable-giving/.

Gnjidic, V. (2018). Interdependence of Company's Industrial Competitive Position and Its Strategic Orientation: A Dynamic Theoretical Model. Management, 23(2), pp. 103-121. https://doi.org/http://hrcak.srce.hr/ management?lang=en

Goggins, A., Howard, D. (2009). SSIR, The Nonprofit Starvation Cycle. Pobrano April 21, 2020 z lokalizacji https:// ssir.org/articles/entry/the_nonprofit_starvation_cycle.

Greenlee J. S., Trussel J. (2000). Predicting the financial vulnerability of charitable organizations. Nonprofit Management and Leadership, 11, 199-210.

Hager M. (2001). Financial Vulnerability among Arts Organizations: A Test of the Tuckman-Chang Measures. Nonprofit and Voluntary Sector Quarterly, 376-392 DOl: 10.1177/0899764001302010.

Hamann P.M., Schiemann F., Bellora L., Guenther T.W. (2013). Exploring the Dimensions of Organizational Performance. A Construct Validity Study. Organizational Research Methods 16(1), 67-87.

Harrison, T., Thornton, J. (January 30, 2015). Entry Thresholds and Competitive Behavior among Nonprofit Firms.

Harvard Business Review. (2014). The Explainer: Porter's Five Forces. Pobrano March 30.03.2020, 2020 z lokalizacji https://hbr.org/video/3590615226001/the-explainer-porters-five-forces.

Heng Q. (2019). Risk and Diversification of Nonprofit Revenue Portfolios: Applying Modern Portfolio Theory to Nonprofit Revenue Management. Nonprofit Management and Leadership, 30(2), 193-212.

Horsley, G. (2019). Four Ways To Engage With Donor Prospects Without Asking For Money. Pobrano April 23, 2020 z lokalizacji https://www.forbes.com/sites/forbesnonprofitcouncil/2019/12/02/four-ways-to-engage-withdonor-prospects-without-asking-for-money/\#36a8b607bbe.

Jay, E., Sargeant , A. (2014). Fundraising Management (3. wyd.). London: Tailor and Francis group Routledge.

Joslyn, H. (2019). 51\% of Fundraisers Plan to Leave Their Jobs by 2021, Says New Survey. Pobrano April 25, 2020 z lokalizacji https://www.philanthropy.com/article/51-of-Fundraisers-Plan-to/246857.

Kafel, T., Ziębicki, B., (2009). Współczesne narzędzia zarządzania organizacjami komercyjnymi. W: Red. A. Nalepka, A. Ujwary-Gil. Organizacje komercyjne i niekomercyjne wobec wzmożonej konkurencji oraz wzrastajacych wymagań konsumentów. WSB-NLU, Nowy Sącz. Pobrano November 11.11.2020, z lokalizacji https://core.ac.uk/reader/48036640

Kitchener, A., Markusen, A. (2012). Working with Small Arts Organizations. Pobrano April 10, 2020 z lokalizacji https://www.giarts.org/article/working-small-arts-organizations

Lloyd, T. (2010). Using Porter's Five Forces to analyse on profit industry. Journal of Productivity Analysis, 35(2), 171-180.

Ma. Guadalupe Diaz Diaz, Chavez Macias, A.G., Pena Cardenas, M.C., Pilar Lopez Saldana, C., and Lluevanos Tellez, A.A. (2017). Strategic Planning: Funding And Transparency In Mexico Nonprofit Organizations (Planeacion Estrategica: Procuracion De Fondos Y Transparencia En Organizaciones De La Sociedad Civil De Mexico), The Institute for Business and Finance Research, 10(6), pp. 65-74. 
Mehta, A. (2016). Fundraising for Success A Guide for Small and Diaspora NGOs. Oxford: INTRAC.

Mikołajczak P. (2019). Finansowe uwarunkowania działalności organizacji pozarządowych, W: Mikołajczak P., Rozwój organizacji pozarzadowych wobec wyzwań współczesności (s. 73-94), CeDeWu.

Mingaleva, Z.A., Deputatova, L.N., Akatov, N.B., Starkov, Y.V., Mitrofanova E. (2019). Application of HADI-cycle for providing sustainability of processes of knowledge and innovation, Entrepreneurship and Sustainability Issues, Vsl Entrepreneurship and Sustainability Center, 7(2), 1628-1640, December.

MTM London. (2016). Private Investment in Culture Survey. London: Arts Council England.

Neely, D., Harris, E. (2018). Determinants and Consequences of Nonprofit Transparency. December 2018. Journal of Accounting, Auditing and Finance. DOI: 10.1177/0148558X18814134.

Nielsen, L. (2019). Example of Tactical Planning in Business. Pobrano March 27.03.2020, 2020 z lokalizacji https:// smallbusiness.chron.com/example-tactical-planning-business-5102.html.

Nonprofits Source. (2020), Pobrano November 08, 2020 z lokalizacji https://nonprofitssource.com/online-givingstatistics.

O'Reilly, B. (2018). Why Don't Donors Trust Us, \& What Can We Do About It? Pobrano April 21, 2020 z lokalizacji https://trust.guidestar.org/why-dont-donors-trust-us-what-can-we-do-about-it.

Piana, D. L. (2001). Real Collaboration A Guide for Grantmakers. Pobrano April 08, 2020 z lokalizacji https://www. issuelab.org/resources/7619/7619.pdf.

Piana, D. L. (2005). Play to Win: The Nonprofit Guide to Competitive Strategy. San-Francisco: Jossey-Bass A Wiley Imprint.

Polivtseva, E. (2020). Performing arts in times of the pandemic Status quo and the way forward. IETM. Pobrano September 17, 2020 z lokalizacji https://www.ietm.org/en/system/files/publications/performing_arts_in_ times_of_the_pandemic_0.pdf.

Porter, M. E. (1996). What is Strategy? Pobrano June 05, 2020 z lokalizacji https://iqfystage.blob.core.windows. net/files/CUE8taE5QUKZf8ujfYIS_Reading+1.4.pdf.

Porter, M. E. (2008). On competition. Harvard Business Press, Pobrano November 05, 2020 z lokalizacji http:// ressources.aunege.fr/nuxeo/site/esupversions/ba0a40a7-4350-475d-a503-2475adcb9925/res/porter.pdf

Ritchie, R., Weinberg, C. (2000). Competition in the Nonprofit Sector: A Strategic Marketing Framework. Social Sciences and Humanities Research Council of Canada. Pobrano September 17, 2020 z lokalizacji http://citeseerx.ist.psu.edu/viewdoc/download?doi=10.1.1.200.8126\&rep=rep1\&type=pdf.

Rose-Ackerman, S. (1982). Charitable Giving and "Excessive" Fundraising. The Quarterly Journal of Economics, 97(2), 193-212.

Saxton, J., Violi, C. (2020). Show me the money! The challenges in how charities present their financial information to the public. London: nfpSynergy. Pobrano April 23, 2020 z lokalizacji https://nfpsynergy.net/blog/covid19-charity-sector.

Seongho S., Yi D. (2011). The fundraising efficiency in U.S. non-profit art organizations: An application of a Bayesian estimation approach using the stochastic frontier production model. Pobrano April 23, 2020 z lokalizacji https://www.jstor.org/stable/23883943.

Sherlock, M. F. (2009). Overview of the Nonprofit and Charitable Sector. DIANE Publishing.

Sinek, S. (2011). How great leaders inspire action. Pobrano April 23, 2020 z lokalizacji https://www.ted.com/talks/ simon_sinek_how_great_leaders_inspire_action/discussion

Te, N. (2020). 40 nonprofit trends for 2020 A balancing act between new, fancy tech tools and traditional fundraising strategies. NonProfit PRO and NAPCO Media. Pobrano 17 09, 2020 z lokalizacji https://www.nonprofitpro. $\mathrm{com} /$ promo/2020-nonprofit-trends-for-2020.

The way that acos operate is changing rapidly across the globe. Effective fundraising and leadership in arts and culture (2020). Online course. University of leeds. Pobrano April 2020 z lokalizacji https://www.futurelearn. com/courses/fundraising-arts-culture.

Thorin's Think Space. (2011). Applying Porter's Five Forces Model to the NGO Sector. Pobrano April 02, 2020 z lokalizacji https://thorinsthinkspace.wordpress.com/2011/09/13/applying-porters-five-forces-model-to-thengo-sector/\#comments.

Tuckman H. P., Chang C. F. (1991). A methodology for measuring the financial vulnerability of charitable nonprofit organizations. Nonprofit and Voluntary Sector Quarterly, 20, 445-460.

Vasicek, D., Sikiric, A. M., Kostic, M. D. (2019). Financial Position and Sustainability of Associations in Croatia. Central European Public Administration Review, 17(1), 93-109.

Vogel, J. (2017). Donor retention: the key to sustainable fundraising. Pobrano March 23.03.2020, 2020 z lokalizacji https://www.donorperfect.com/nonprofit-technology-blog/fundraising-software/donor-retention. 
Woronkowicz, J., Nicholson-Crotty, J. (2017). The Effects of Capital Campaigns on Other Nonprofits' Fundraising. Nonprofit Management and Leadership, 27(3), 371-387. Pobrano June 02, 2020 z lokalizacji https://doi. org/http://onlinelibrary.wiley.com/journal/10.1002/\%28ISSN\%291542-7854/issues.

Ziębicki, B. (2008). Ewolucja modeli efektywności organizacyjnej. W: red. A. Stabryła. Zarządzanie rozwojem organizacji w społeczeństwie informacyjnym. Wydawnictwo Uniwersytetu Ekonomicznego w Krakowie, Kraków, tom 2.

\section{Fundraising competitive forces of small art and cultural NGOs during the crisis}

Summary: The paper provides an analysis on fundraising competitive forces of small art and culture organizations in order to identify optimal features of fundraising strategy development during and after crisis time when absence of donors becomes a pressing issue.The analysis is fulfilled based on Michael Porter five forces model structure.

Fundraising strategies should focus on intensive development of advanced communication with donors through modern technology application and reflect an integral vision of social needs which is the key success factor of fundraising strategy implementation in independent autonomous organizations. Financial resources in nonprofit sector seriously affect the stability of programs implementation. The lack of stability undermines organization efficiency what is evident to donors. This requires formulation of strategy for professional and repetitive fundrising.

Keywords: fundraising; small; medium; cultural; non-profit; organization

JEL codes: L31; L23

\section{Informacje o autorkach}

\section{Olesya Radilova, MA}

Independent research fellow within Kirkland Scholarship 2019/20.

Uniwersytet im. Adama Mickiewicza w Poznaniu ul. Wieniawskiego 1 61-712 Poznań

e-mail: olesya.radilova@gmail.com

* Autor korespondencyjny/Corresponding author
Agnieszka Ziomek, dr hab. prof. UEP*

ORCID: 0000-0001-7052-5855

Katedra: Koniunktury i Polityki Gospodarczej

Instytut Ekonomii

Uniwersytet Ekonomiczny w Poznaniu

Al. Niepodległości 10, 61-875 Poznań

e-mail: agnieszka.ziomek@ue.poznan.pl

\section{Prawa autorskie i licencja / Copyright and License}

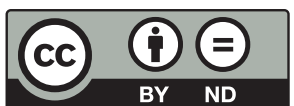

Publikacja na licencji Creative Commons Uznanie autorstwa Użycie niekomercyjne - Bez utworów zależnych 4.0 Międzynarodowe (CC BY-ND 4.0) http://creativecommons.org/licenses/by-nc-nd/4.0/deed/pl

This work is published under the terms of the Creative Commons Attribution - NoDerivetives International (CC BY-ND 4.0) License http://creativecommons.org/licenses/by-nc-nd/4.0
Wydane przez Uniwersytet Ekonomiczny w Krakowie. Małopolska Szkoła Administracji Publicznej

Published by Cracow University of Economics - Krakow, Poland. Małopolska School of Public Administration of the Cracow University of Economics 